口絵 2 : 新潟県十日町市蒲生地区の泥火山における CSAMT法およびレーザー測量結果

\title{
Pictorial 2 : Results of the Laser Scanner and the CSAMT Surveys Carried out in the Kamou Area, Tokamachi City, Niigata Prefecture
}

新潟県十日町市蒲生地区に分布する泥火山の周辺には特徵的な地形や地質構造が見られる。レーザー測量により泥火山周辺に“す り鉢状地形”が認められ，その周囲は地質構造が乱れている。また，整然とした地層と乱れた地質構造との境界部には湧水・ガス の噴出する泥火山が分布している. CSAMT (Controlled Source Audio-frequency Magneto-Telluric) 法探査によって，すり鉢状 地形の下部に明らかとなった低比抵抗体は，海水と同程度の塩分濃度の地下水あるいは泥で充填された泥溜まりを捕らえたものと 推定される。詳細は本特集号鈴木ほか論文（p.373-389）を参照.

Typical topographic features and geological structures are found near the mud volcanoes in the Kamou area, Tokamachi City, Niigata Prefecture. The laser measurements found the topographic depression and the geological survey determined that the geological structure around the depression is intensely disturbed. The mud volcanoes erupting groundwater and natural gas are distributed between the disturbed and undisturbed formations. The extremely low resistivity zone detected below the topographic depression by the CSAMT (Controlled Source Audio-frequency Magneto-Telluric) survey is estimated to correspond to a mud chamber filled with saline groundwater and mud. See the article by Suzuki et al. (p.373-389).

A EL. N

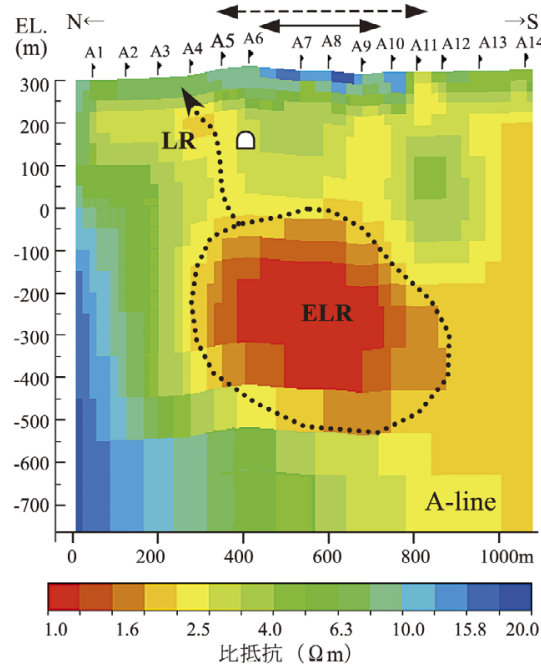

蒲生泥火山

松泉寺泥火山露頭

○鍋立山トンネル

$\longrightarrow$ 一地質構造の乱れた地域(新谷·田中, 2005)

$\longrightarrow$ 于り錸状地形

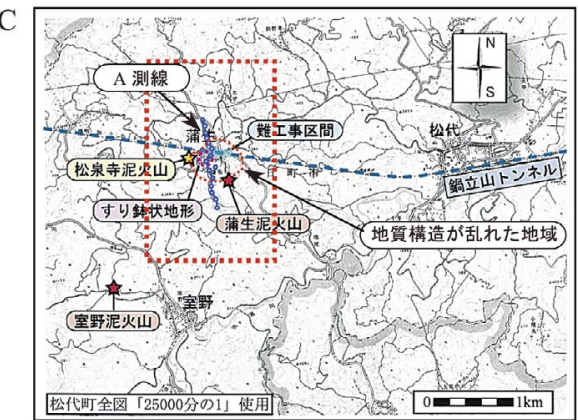

B

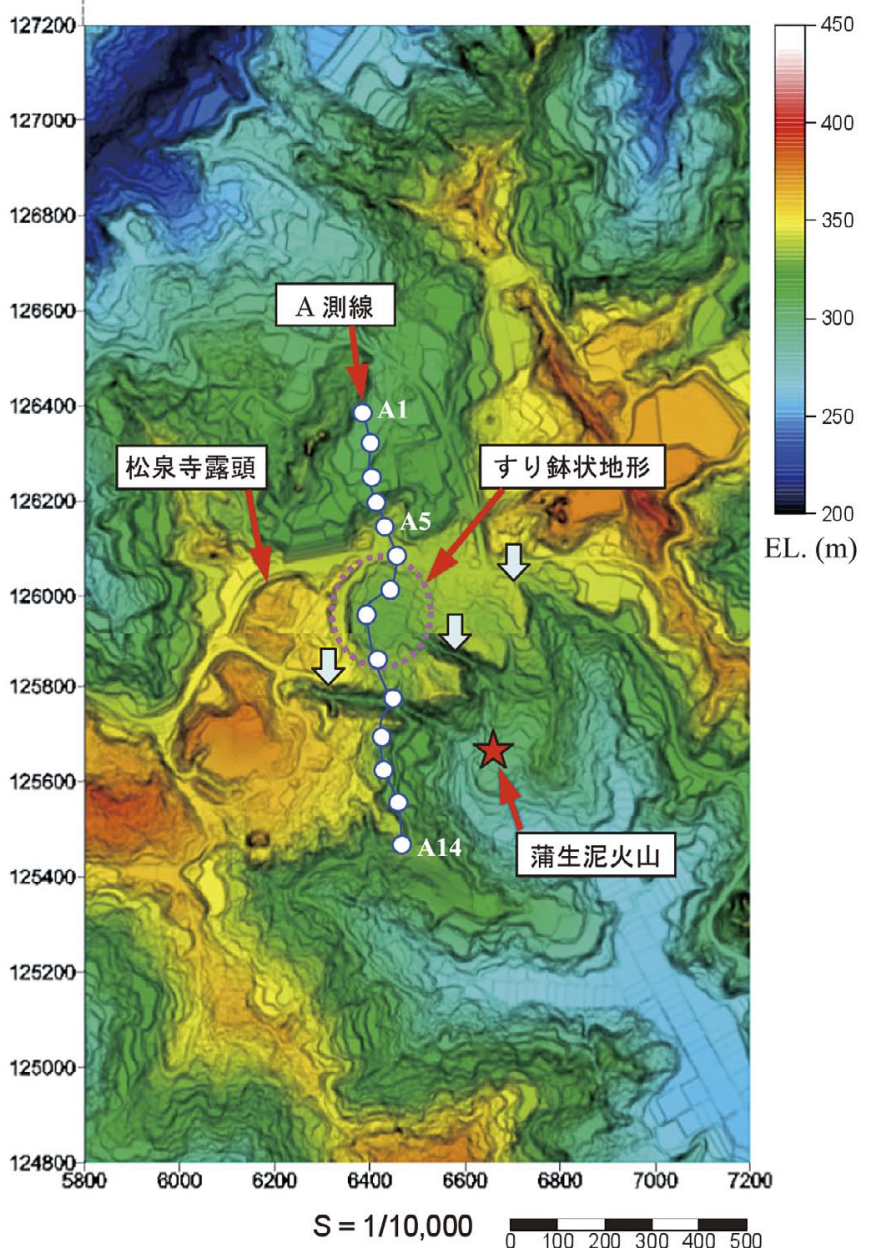

図 1 A：CSAMT 法による比抵抗断面図. 地質構造の乱れた地域の下部，深度 $300 \sim 700 \mathrm{~m}$ 区間（EL. $0 \sim-400 \mathrm{~m} ）$ に $1.6 \Omega \mathrm{m}$ 以下と極めて低い比抵抗体（ELR）が存在する。この ELRの北端部から測点 A5 の方向に, ELRよりは若干高い $1.6 \sim 2.5$ $\Omega \mathrm{m}$ の低比抵抗体 $(\mathrm{LR})$ がのびており，鍋立山トンネルはその途中に位置している. EL. は標高, トンネルのサイズは拡 大して表示. B : レーザースキャナーによる地形調査結果. 3 箇所の矢印は深く切り込む沢を示す。 C : レーザー測量の調 査範囲と CSAMT 法による解析断面位置を示す。青い破線は鍋立山トンネルの位置を示す。

Fig. 1 A: The resistivity profile by the CSAMT survey. The extremely low resistivity zone (ELR) at a depth of 300 to $700 \mathrm{~m}$ (elevation 0 to $-400 \mathrm{~m}$ ) with resistivity of less than $1.6 \Omega \mathrm{m}$ is present in a geologically disturbed area. The low resistivity zone (LR) with resistivity between 1.6 and $2.5 \Omega \mathrm{m}$ is also present and can be traced to Location A5, where the Nabetachiyama Tunnel is located. EL. shows altitude. The size of the tunnel is exaggereated. B: Topographic features obtained by the Laser scanner survey. Three arrows indicate steep valleys. C: Map showing the area of the Laser scanner survey and the analytical line of the CSAMT survey. Blue broken line shows the Route of the Nabetachiyama Tunnel. 